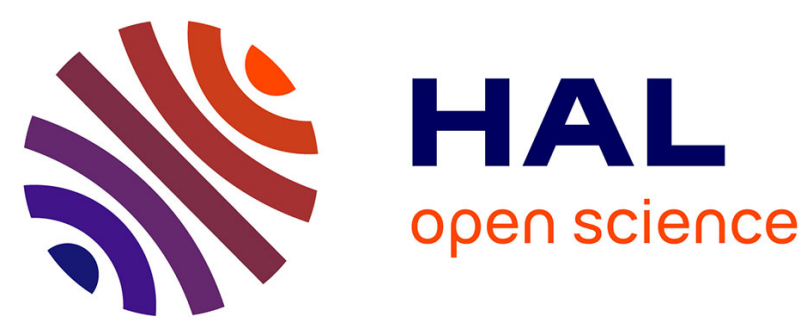

\title{
Assessing the benefit of the 72-hour antibiotic therapy reassessment documentation
}

V. Pérut, R. Gauzit, S. Kernéis, E. Canouï, F.X. Chedhomme, R. Batista, O. Conort, S. Bouam, J. Raymond, J. Loubinoux, et al.

\section{- To cite this version:}

V. Pérut, R. Gauzit, S. Kernéis, E. Canouï, F.X. Chedhomme, et al.. Assessing the benefit of the 72-hour antibiotic therapy reassessment documentation. Médecine et Maladies Infectieuses, 2019, 49, pp.187 - 193. 10.1016/j.medmal.2018.10.002 . hal-03486843

\section{HAL Id: hal-03486843 \\ https://hal.science/hal-03486843}

Submitted on 20 Dec 2021

HAL is a multi-disciplinary open access archive for the deposit and dissemination of scientific research documents, whether they are published or not. The documents may come from teaching and research institutions in France or abroad, or from public or private research centers.
L'archive ouverte pluridisciplinaire HAL, est destinée au dépôt et à la diffusion de documents scientifiques de niveau recherche, publiés ou non, émanant des établissements d'enseignement et de recherche français ou étrangers, des laboratoires publics ou privés.

\section{()ㅜ(1)}

Distributed under a Creative Commons Attribution - NonCommercial| 4.0 International 


\title{
Évaluation de l'intérêt de la traçabilité de la réévaluation de l'antibiothérapie à
}

\section{2 heures}

\section{Assessing the benefit of the 72-hour antibiotic therapy reassessment documentation}

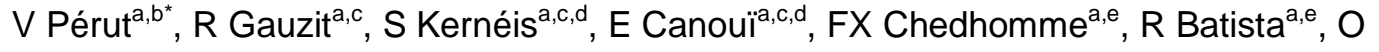

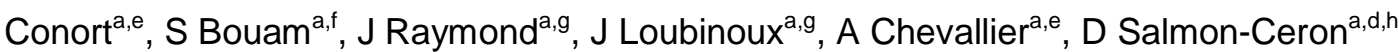

a Commission Médicale des Anti-Infectieux (COMAI) des Hôpitaux universitaires Paris Centre, Assistance Publique-Hôpitaux de Paris, Paris, France

${ }^{\text {b }}$ Service de Santé Publique, Unité de Gestion des Risques et Qualité, Assistance PubliqueHôpitaux de Paris, Hôpitaux Universitaires Paris Centre, Paris, France

c Équipe Mobile d'Infectiologie, Assistance Publique-Hôpitaux de Paris, Hôpitaux Universitaires Paris Centre, Paris, France

${ }^{d}$ Université Paris Descartes, Faculté de Médecine, Sorbonne Paris Cité, Paris, France

${ }^{\text {e }}$ Service de Pharmacie des Hôpitaux Universitaires Paris Centre, Assistance PubliqueHôpitaux de Paris, Paris, France

f Unité d'Information Médicale, Assistance Publique-Hôpitaux de Paris, Hôpitaux Universitaires Paris Centre, Paris, France

${ }^{g}$ Service de Bactériologie, Assistance Publique-Hôpitaux de Paris, Hôpitaux Universitaires Paris Centre, Paris, France

h Service de Maladies Infectieuses, Assistance Publique-Hôpitaux de Paris, Hôpitaux Universitaires Paris Centre, Paris, France

\section{*Corresponding author}

Email address: valerie.perut@aphp.fr (V. Pérut)

Tel : 0158412679

Parts of these findings have been presented as a poster and an oral presentation at the $35^{\text {th }}$ RICAI in Paris, December 2015. 
Keywords: antibiotic therapy, de-escalation, reassessment

Mots clés : antibiothérapie ; désescalade ; réévaluation 


\section{Résumé}

Objectifs. Évaluer la traçabilité de la réévaluation de l'antibiothérapie à $72 \mathrm{~h}$ dans le dossier médical.

Méthode. Évaluation un jour donné des antibiothérapies curatives $\geq 72 \mathrm{~h}$. La traçabilité de la réévaluation a été définie selon trois critères : 1) traçabilité « explicite » (commentaire clinique ou microbiologique et commentaire sur la nécessité ou non d'adapter l'antibiothérapie), 2) traçabilité « implicite » (commentaire uniquement clinique ou microbiologique), 3) absence de traçabilité.

Résultats. Évaluation de 114 antibiothérapies dans 26 unités de soins. Seuls 45 (39\%) dossiers comportaient une réévaluation explicite à $72 \mathrm{~h}$ et $31(27 \%)$ ne comportaient aucune réévaluation. La durée prévisionnelle de traitement était notée dans 63 (55\%) dossiers. À $72 h$, sur les 71 antibiothérapies avec documentation microbiologique, 69 (97\%) étaient actives et $44(62 \%)$ avaient un spectre étroit. Parmi les 48 antibiothérapies avec un spectre élargi à J1, seules $21(44 \%)$ ont bénéficié d'une désescalade à $72 \mathrm{~h}$. Une réévaluation explicitement tracée à $72 \mathrm{~h}$ était associée à une désescalade $(p=0.025)$ et la prescription de la durée prévisionnelle de traitement était associée à une antibiothérapie conforme aux recommandations locales ou nationales $(p=0.018)$.

Conclusion. Bien qu'une réévaluation ait été notée dans $73 \%$ des dossiers, celle-ci était correctement tracée à $72 \mathrm{~h}$ dans seulement $39 \%$ des cas. La traçabilité de la réévaluation et la prescription de la durée prévisionnelle de traitement étaient associées à une meilleure qualité de la prescription (désescalade, adéquation avec les recommandations) et constituent des indicateurs pertinents du suivi du bon usage des antibiotiques. 


\section{Abstract}

Objectives. To assess the documentation of the 72-hour antibiotic therapy reassessment in medical records.

Methods. One-day prevalence evaluation of curative antibiotic therapies $\geq 72$ hours. The documentation of the reassessment was defined according to three criteria: 1) "clear" documentation (clinical or microbiological comment associated with a comment on the need to adjust the antibiotic therapy or on the lack of need) 2) "tacit" documentation (only based on a clinical or microbiological comment), 3) no documentation.

Results. We assessed 114 antibiotic therapies in 26 hospital departments. A clear reassessment at 72 hours was observed in only 45 (39\%) records and 31 (27\%) records had no reassessment. The planned duration of treatment was written in 63 (55\%) records. At 72 hours, among the 71 antibiotic therapies with a microbiological documentation, 69 (97\%) were active and $44(62 \%)$ had a narrow spectrum. Among the 48 antibiotic therapies with a broad spectrum on Day 1, only $21(44 \%)$ benefited from a de-escalation at 72 hours. A clearly recorded reassessment at 72 hours was associated with de-escalation $(p=0.025)$ and the prescription of a planned duration of treatment was associated with antibiotic therapy compliance with local or national guidelines $(p=0.018)$.

Conclusion. Although reassessment was observed in $73 \%$ of records, it was correctly recorded at 72 hours in only $39 \%$ of cases. The documentation of the reassessment and the prescription of a planned duration were associated with a better quality of antibiotic prescription (de-escalation, compliance with guidelines) and are relevant indicators for monitoring the proper use of antibiotics. 


\section{INTRODUCTION}

Improving the quality of antibiotic prescriptions in hospital settings is a key objective of antibiotic stewardship programs to tackle the development of resistance [1]. The 2011-2016 French national antibiotic plan [2] recommends reassessing antibiotic prescriptions at 48-72 hours. Prescription reassessment allows physicians to adjust the empirical treatment based on bacteriological findings. The aim is to optimize the antibiotic therapy, to discontinue any useless treatment, and to reduce the selection pressure.

According to the French National Authority for Health (French acronym HAS) guidelines [3], the 24-72-hour reassessment must be documented in the patient's medical record and it is one of the criteria taken into consideration by the composite score for antibiotic stewardship (ICATB.2) [4].

To our knowledge very few French studies assessed the documentation of antibiotic therapy reassessment in medical records. Available studies only focused on specific antibiotics and/or specific wards $[5,6,7]$. The relation between a documented reassessment in medical records and the antibiotic therapy compliance with guidelines has only been assessed in one study [5].

We aimed to assess the documentation of the 72-hour antibiotic therapy reassessment in medical records, the mention of a planned treatment duration prescription, and the quality of antibiotic prescriptions (adequate spectrum of activity, compliance with local or national guidelines) in the various wards of a 1,500-bed teaching hospital of Paris.

\section{METHOD}

We performed a one-day prevalence cross-sectional survey in 2014 in the teaching hospitals of the center of Paris (French acronym HUPC) based on data documented in the medical records. 
The HUPC hospital group includes the Cochin Hospital (903 beds), the Hôtel-Dieu Hospital (28 beds), and the geriatric Broca Hospital (558 beds). The HUPC is part of the public hospital system of the city of Paris (French acronym AP-HP).

A total of 29 wards were surveyed: medicine, geriatrics, surgery, obstetrics, and intensive care units (ICUs). All patients of each ward receiving a curative antibiotic therapy for at least 72 hours were included in the study, irrespective of the empirical or documented nature of the prescription. Antibiotic therapies initiated in a ward other than the one surveyed (except for the emergency ward), antibiotic prophylaxes, antibiotic therapies administered through another route than the oral or injection route, antibiotic therapies prescribed as part of a tuberculosis treatment, HIV opportunistic infections, or parasitic infections were excluded. We only took into consideration the first antibiotic therapy administered to patients who had received several antibiotic therapies during a single stay.

The main objective of the survey was to assess the documentation of the 72-hour antibiotic therapy reassessment in the medical records. The secondary objectives were 1) to assess the mention of a planned treatment duration prescription, 2) to assess the adequacy of the antibiotic therapy (adequate spectrum of activity based on microbiological data or compliance with local or national guidelines), 3) to look for a relation between the documentation of the antibiotic therapy reassessment in the medical record or the mention of a planned treatment duration prescription and the antibiotic therapy adequacy.

A data collection grid was designed by a working group including physicians, bacteriologists, and pharmacists - all were members of the Committee for anti-infective agents (French acronym COMAI) of the HUPC - based on the HAS guidelines on antibiotic stewardship [3], ICATB.2 criteria [4], and on the regional survey on antibiotic therapy reassessment at 72 hours performed by the health authorities (Omédit and Arlin) of the Haute-Normandie region [8].

The following data was collected for all evaluated antibiotic therapies: ward, infection portal of entry, presence of bacteriological results (type of bacterium and antimicrobial susceptibility 
testing), potential associated bacteremia, prescribed molecule(s) on day 1 and day 3, written mention in the medical record of the diagnosis leading to the prescription, mention of a planned treatment duration prescription, and potential intervention of an infectious disease mobile team. The documentation of a reassessment was looked for in medical records within the first 72 hours following antibiotic therapy initiation. Three types of reassessment documentation were defined: 1) "clear" documentation: presence of a clinical or microbiological comment associated with a comment on the need or lack of need for an antibiotic therapy change, 2) "tacit" documentation: clinical or microbiological comments only, without any comment on the antibiotic therapy prescribed, 3) absence of documentation.

When microbiological documentation was present the antibiotic therapy was considered adequate if it was active against the documented bacteria and if the chosen molecule had the best spectrum of activity possible based on the antimicrobial susceptibility test results [9]. Treatment de-escalation was defined as a treatment change leading to the prescription of a molecule with the narrowest spectrum of activity possible. When no microbiological documentation was present the antibiotic therapy was considered adequate if it complied with the local or national guidelines.

The data collection grid was tested in June-July 2014. Data was collected on a given day in each ward between July and October 2014, based on the paper or computerized medical records. Investigators were infectious disease specialists, bacteriologists, and pharmacists, and all were members of the COMAI of the HUPC.

Data was analyzed using the SPSS software, version 17.0. Qualitative variables were expressed as frequencies and $95 \%$ confidence intervals as per the binomial distribution. On the basis of the bivariate analysis, the relation between 1) the clear documentation of a reassessment at 72 hours, 2) the prescription of a planned treatment duration and the categorical variables was tested using a Chi-square test or Fisher's exact test if the theoretical 
expected numbers in each category were $<5$ (bilateral test, significance threshold was set at $p<0.05)$.

\section{RESULTS}

The investigators analyzed 167 stays associated with one antibiotic therapy prescription in 29 hospital wards. No curative antibiotic therapy had been prescribed on the day of the survey in three wards (maternity ward, endocrinology, physical rehabilitation). Overall, 114 antibiotic therapies (Table 1) meeting the inclusion criteria were assessed: $49(43 \%)$ in the medical wards, $26(23 \%)$ in the geriatric wards, $24(21 \%)$ in the surgical wards, and $15(13 \%)$ in the ICUs. Infections were community-acquired in $43 \%(n=49)$ of cases, healthcare-associated in $51 \%(n=58)$, and of unknown origin in $6 \%(n=7)$ of cases.

Among the 114 antibiotic therapies assessed, 66 (58\%) were monotherapies prescribed on day 1 and $65(57 \%)$ on day 3, $40(35 \%)$ were two-drug combination therapies prescribed on day 1 and $44(39 \%)$ on day 3, and eight (7\%) included three or four antibiotics prescribed on day 1 and five (4\%) on day 3 . The three most frequently prescribed antibiotics among the 170 prescribed on day 1 were ceftriaxone $(n=32,19 \%)$, tazocilline $(n=23,14 \%)$, and metronidazole $(n=18,11 \%)$.

The three most frequent portals of entry were the lungs, the urinary tract, and the gastrointestinal tract. At 72 hours $16(14 \%)$ patients did not have any microbiological sample taken, one bacterium or several bacteria had been isolated in $71(62 \%)$ patients, and seven (6\%) results were pending. Among the 110 isolated bacteria, the most frequent were

Escherichia coli $(n=30,27 \%)$, Klebsiella pneumoniae $(n=11,10 \%)$, Staphylococcus epidermidis $(n=10,9 \%)$, Staphylococcus aureus $(n=7,6 \%)$, and Pseudomonas aeruginosa $(n=7,6 \%)$.

The adequacy of documented and empirical antibiotic therapies at 72 hours is detailed in Table 2. 
Two (3\%) of the 71 antibiotic therapies with microbiological documentation were inactive in vitro against the bacterium or bacteria documented at 72 hours. A molecule with a narrower spectrum of activity could have been prescribed at 72 hours for 48 of these antibiotic therapies, but the de-escalation could not be performed in 27 (56\%) patients. Fourteen (52\%) of these 27 antibiotic therapies without de-escalation at 72 hours were associated with clear documentation of the reassessment at 72 hours and/or with a change in the antibiotic therapy between day 1 and day 3 .

Eleven (26\%) of the 43 antibiotic therapies prescribed in the absence of microbiological documentation did not comply with local or national guidelines at 72 hours.

Overall, $38(33 \%)$ antibiotic therapies were not adequate at 72 hours (i.e., inadequate spectrum or non-compliant with guidelines): $19 \%(5 / 26)$ in the geriatric wards, $33 \%(16 / 49)$ in the medical wards, 37\% (9/24) in the surgical wards, and $53 \%(8 / 15)$ in the ICUs, without any significant difference between the wards. The inadequacy of prescriptions observed in the ICUs was mainly due to the non-prescription of a molecule with a narrower spectrum.

The planned duration of the antibiotic therapy was mentioned in $55 \%$ of medical records (Table 3): $96 \%(25 / 26)$ in the geriatric wards, $53 \%(8 / 15)$ in the ICUs, $46 \%(11 / 24)$ in the surgical wards, and $39 \%(19 / 49)$ in the medical wards $(p<0.0001)$. When no microbiological documentation was available, the prescription of a planned treatment duration was significantly associated with compliance with local or national guidelines ( $90 \%$ versus $59 \%, p=0.018$ ).

The antibiotic therapy reassessment at 72 hours was clearly documented in $39 \%$ of medical records: $54 \%(14 / 26)$ in the geriatric wards, $41 \%(20 / 49)$ in the medical wards, $25 \%(6 / 24)$ in the surgical wards, and 33\% (5/15) in the ICUs, without any significant difference between the wards. 
Overall, only $23(21 \%)$ antibiotic therapies were adequate and associated with clear documentation of the 72-hour reassessment and with planned treatment durations.

The bivariate statistical analysis revealed that a clearly documented 72-hour reassessment was significantly associated with antibiotic therapy de-escalation to prescribe a narrower spectrum molecule (62\% versus $30 \%, p=0.025)$.

\section{DISCUSSION}

This study was performed on a given day in 26 hospital wards and included all curative antibiotic therapies (irrespective of the infection site) prescribed on that day. Findings from the study give an "instant" and quite accurate representation of the quality of antibiotic therapy reassessment at 72 hours in a teaching hospital of Paris. Findings reveal that the 72 -hour reassessment and the planned treatment duration are only clearly documented in one in four medical records, while such documentation is significantly associated with the better quality of the antibiotic therapy prescription (de-escalation, compliance with local or national guidelines).

Other recent studies reported similar results: $49 \%$ of clearly documented reassessments at 72 hours in 2012 in 33 health facilities of Haute-Normandie [8], 39\% in 2014 for fluoroquinolone prescriptions made in the neurology department of a teaching hospital of Toulouse [6], 54\% in 2015 for amoxicillin-clavulanic acid prescriptions made at the APHP [7]. It is, however, difficult to compare these results as the studies did not use the same definition for the documentation of the 72-hour reassessment in medical records.

The low rate of documented reassessments in the medical records may be explained by the absence of writing habits in hospitals, hence the lack of time dedicated to such a timeconsuming activity. This may also highlight the lack of benefit perception for a rational and written "justification" of medical prescriptions on the quality of management as well as poor 
knowledge of its regulatory nature. Documentation is most likely often viewed as an administrative requirement rather than a medical task per se.

However, the HAS guidelines [3] mention that the reassessment of the antibiotic therapy must always be documented in the patient's medical record at 72 hours. Even though the clinical efficacy and tolerability of the antibiotic therapy are reevaluated on a daily basis at the patient's bedside, the reassessment findings must be officially documented in medical records once microbiological data has been obtained and always taking into account the clinical outcome. Treatment reassessment is therefore ensured, and clinical and microbiological data considered to decide on the continuation or change of the antibiotic therapy is clearly documented $[10,11]$.

Although almost all microbiologically documented antibiotic therapies of our study were active at 72 hours, de-escalation was only performed in $44 \%$ of possible cases. Other studies [12,13] also reported that antibiotic therapies were not always reassessed at 72 hours and properly adapted to the microbiological data. Twenty per cent of the microbiologically documented antibiotic therapies of our study had been reassessed at 72 hours (i.e., change in antibiotic therapy and/or clearly documented reassessment) without reduction of the antibiotic spectrum. This finding highlights the insufficient mastering of antibiotic de-escalation criteria by prescribers. The physicians' reluctance to change a susceptible and clinically effective antibiotic therapy and the lack of consideration related to the collective interest of reducing the antibiotic pressure could also explain the absence of de-escalation.

Microbiologically documented antibiotic therapies with a clear documentation of the 72-hour reassessment were more often associated with de-escalation. Prescribers with the best knowledge in antibiotic stewardship may be those spending the most time to clearly document antibiotic therapy reassessment. This could improve the quality of antibiotic prescriptions. However, this has not been unequivocally demonstrated. Pulcini et al. [5] demonstrated that better documentation of the 72-hour reassessment did not improve the quality of antibiotic 
prescriptions, especially de-escalation. However, the authors used slightly different criteria for defining documentation in the medical records, e.g. prescribers were not asked to note whether the antibiotic therapy had to be adapted.

The planned duration of the antibiotic therapy was mentioned in only $55 \%$ of the evaluated medical records. This figure, although low, is higher than those reported in other studies $[6,14,15]$ : from $24 \%$ to $40 \%$. The prescription of a planned duration for the antibiotic therapy mentioned in the medical record was significantly associated with treatment compliance with local or national guidelines. This probably reflects on the prescribers' knowledge of guidelines. Treatment duration suggestions recently published by the Guidelines Committee of the SPILF [16] should help reduce the duration of many antibiotic therapies and improve monitoring.

Our study findings seem to suggest that physicians should be made aware of the benefit of documenting the adaptation or lack of adaptation of the antibiotic therapy at 72 hours in the patient's medical record. Focus should be put on improving prescription quality which will help tackle the emergence of resistance. The awareness of physicians should also be raised on the regulatory aspect of reassessment documentation. Physicians must therefore be informed that antibiotic therapy reassessment will be taken into consideration in the quality-dependent payment process - which is starting to be implemented - and that it is one of the certification criteria for health facilities. However, prescribers must be assisted in better documenting the antibiotic therapy reassessment and in improving prescription quality. IT tools are available or are being developed, such as signals set up on the prescription software as a reminder for the 72-hour reassessment or reminder questionnaires asking prescribers if the antibiotic therapy can be discontinued, shorten, or changed to prescribe a narrower spectrum antibiotic. However, these tools are not extensively used or are even not compatible with existing IT systems. The pharmacists of our study working in geriatrics send a message to geriatricians via the prescription software, asking them to reassess the antibiotic therapy, but the impact of 
such message seems to be limited because no significant difference was observed on the clear documentation of the 72-hour reassessment compared with the other wards. Various studies reported the same finding $[5,13,17]$ and demonstrated the limited impact of these IT tools on the quality of prescriptions. Treatment reassessment is not enough if physicians are not well aware of the criteria for a proper antibiotic prescription. Official guidance for antibiotic prescribing should therefore be provided through antibiotic therapy advice given to prescribers by infectious disease mobile teams with close collaboration with the pharmacy, the microbiological ward, and the operational hygiene team. Numerous studies agree with this strategy $[13,18,19]$ and highlight the positive impact of the intervention of an infectious disease specialist on the quality of antibiotic prescriptions. Easily accessible training, especially e-learning modules, guidelines, and regular evaluations of prescriptions with feedback may also improve the prescribers' knowledge [20, 21, 22].

Implementing and monitoring these improvement strategies require time and human means, which are often lacking. Major multidisciplinary involvement was required to perform this study with the pharmacy, the microbiological ward, the infectious disease mobile team, the operational hygiene team, the COMAI, and the infection control committee (French acronym CLIN). The implementation of computerized medical records in the whole hospital group and in all wards, should help reduce the time dedicated to data collection for future studies. The documentation of the antibiotic therapy reassessment and the prescription of a planned duration for the antibiotic therapy in the medical record can, however, be regularly performed. This is relevant to monitor the effectiveness of the means used to improve both of these indicators.

Part of our study was performed during summer and three wards did not have any antibiotic therapy to evaluate on the day of the survey. This could have led to underestimating the number of curative antibiotic therapies prescribed. 
To make data collection easier we decided to only assess the relevance of the prescribed molecule, and we did not assess the dosing regimen, administration modalities, and prescription duration.

\section{CONCLUSION}

The antibiotic therapy reassessment at 72 hours must be better documented in the medical records to comply with regulations but mainly to improve the quality of prescriptions and their compliance with guidelines, and to limit the emergence of bacterial resistance in microbiota. This indicator seems to be relevant and will regularly be evaluated in our facility. The use of IT tools could help document the antibiotic therapy reassessment but will not be enough to improve the quality of prescriptions if no assistance to prescribing is provided alongside a longterm involvement of physicians to tackle the emergence of multidrug-resistant bacteria.

\section{Declaration of interests}

The authors declare no competing interests.

\section{Contribution of authors}

V. Perut designed the study protocol, wrote the initial version of the article, and performed the statistical analyses.

R. Gauzit contributed to designing the study protocol and to collecting data, and wrote the final version of the article.

S. Kernéis, S. Bouam, F.X. Chedhomme, R. Batista, O. Conort, J. Loubinoux, A. Chevallier, and J. Raymond contributed to designing the study protocol and to collecting data and reviewed the final version of the article.

E. Canouï reviewed the final version of the article.

D. Salmon-Ceron designed the study protocol, contributed to interpreting the data, and wrote the final version of the article. 


\section{REFERENCES}

[1] Schuts EC, Hulscher MEJL, Mouton JW, Verduin CM, Stuart JWTC, Overdiek HWPM, et al. Current evidence on hospital antimicrobial stewardship objectives: a systematic review and metaanalysis. Lancet Infect Dis. 2016 Jul;16(7):847-56.

[2] Ministère du travail, de l'emploi et de la santé. Plan national d'alerte sur les antibiotiques 20112016. Disponible sur http://social-sante.gouv.fr/lMG/pdf/plan_antibiotiques_20112016_DEFINITIF.pdf. (accessed on February 15, 2017).

[3] Haute Autorité de Santé. Manuel de certification des établissements de santé v2010-revise-janvier2014. Disponible sur http://www.has-sante.fr/portail/upload/docs/application/pdf/201403/manuel_v2010_janvier2014.pdf. (accessed on February 15, 2017).

[4] Haute Autorité de Santé. Indicateurs de qualité et de sécurité des soins. Thème Infections Associées Aux Soins (IAS). Fiche descriptive de l'indicateur composite de bon usage des antibiotiques (ICATB2). Mars 2016. Disponible sur http://www.hassante.fr/portail/upload/docs/application/pdf/2016-04/2016_has_fiche_descriptive_icatb_2.pdf. (accessed on February 15, 2017).

[5] Pulcini C, Dellamonica J, Bernardin G, Molinari N, Sotto A. Impact of an intervention designed to improve the documentation of the reassessment of antibiotic therapies in an intensive care unit. Med Mal Infect. 2011 Oct;41(10):546-52.

[6] P. Calvet, C. Rouzaud-Laborde. Primo-prescription de fluoroquinolones dans les services de neurologie et réévaluation à 48-72 heures : une expérience du Centre hospitalier universitaire de Toulouse. Pharmactuel 2016; 49(1) : 49-55.

[7] I. Fusier, et al. Amoxicillin-clavulanic acide prescriptions at the Greater Paris University Hospitals (AP-HP) Med Mal Inf (2017); 47(1) : 42-49.

[8] M. Lucas, et al. Réévaluation de l'antibiothérapie avant la $72^{\text {ème }}$ heure : quelles traces dans les dossiers? Une enquête régionale. Disponible sur http://www.cclinparisnord.org/REGION/HTN/ EnqReevalATB2012_Ricai.pdf. (accessed on February 15, 2017).

[9] Weiss E, Zahar J-R, Lesprit P, Ruppe E, Leone M, Chastre J, et al., De-escalation Study Group. Elaboration of a consensual definition of de-escalation allowing a ranking of $\beta$-lactams. Clin Microbiol Infect. 2015 Jul;21(7):649.e1-10.

[10] Haute Autorité de Santé. Stratégie d'antibiothérapie et prévention des résistances bactériennes. Recommandations professionnelles. 2008. Disponible sur http://www.hassante.fr/portail/upload/docs/application/pdf/bon_usage_des_antibiotiques_rapport_complet.pdf. (accessed on February 15, 2017).

[11] Société de pathologie infectieuse de langue française. Comment améliorer la qualité de l'antibiothérapie dans les établissements de soins ? Med Mal Infect 2002 ;32:320-8.

[12] U. Fluckiger, W. Zimmerli, H. Sax, R. Frei, A.F. Widmer. Clinical impact of an infectious disease service on the management of bloodstream infection. Eur J Clin Microbiol Infect Dis (2000) 19:493500 .

[13] Lesprit P, Landelle C, Girou E, Brun-Buisson C. Reassessment of intravenous antibiotic therapy using a reminder or direct counselling. J Antimicrob Chemother. 2010 Apr;65(4):789-95.

[14] Mechkour S, Vinat A, Yilmaz M, Faure K, Grandbastien B. [Quality of antibiotic (fluoroquinolons, aminosids and amoxicillin-clavulanic acid) prescription in a French teaching hospital]. Pathol Biol. 2011 Feb;59(1):9-15. 
[15] Borderan G-C, Mignot L, Bonnan J, Faure P, Blanc S, Lelievre I, et al. [Evaluation of antibiotic curative treatments in a French orthopedic surgery unit]. Med Mal Infect. 2010 May;40(5):285-91.

[16] Wintenberger C, Guery B, Bonnet E, Castan B, Cohen R, Diamantis S, et al., Recommendation Group of the SPILF. Proposal for shorter antibiotic therapies. Med Mal Infect. 2017 Mar;47(2):92141.

[17] Senn L, Burnand B, Francioli P, Zanetti G. Improving appropriateness of antibiotic therapy: randomized trial of an intervention to foster reassessment of prescription after 3 days. J Antimicrob Chemother. 2004 Jun;53(6):1062-7.

[18] Rimawi RH, Mazer MA, Siraj DS, Gooch M, Cook PP. Impact of regular collaboration between infectious diseases and critical care practitioners on antimicrobial utilization and patient outcome. Crit Care Med. 2013 Sep;41(9):2099-107.

[19] De La Blanchardière A, Boutemy J, Thibon P, Michon J, Verdon R, Cattoir V. Clinical benefit of infectious diseases consultation: a monocentric prospective cohort study. Infection. 2012 Oct;40(5):501-7.

[20] Nicolle LE. Antimicrobial stewardship in long term care facilities: what is effective? Antimicrob Resist Infect Control. 2014 Feb 12;3(1):6.

[21] Stach LM, Hedican EB, Herigon JC, Jackson MA, Newland JG. Clinicians' Attitudes Towards an Antimicrobial Stewardship Program at a Children's Hospital. J Pediatric Infect Dis Soc. 2012 Sep;1(3):190-7.

[22] Van Schooneveld T. Antimicrobial stewardship: attempting to preserve a strategic resource. J Community Hosp Intern Med Perspect. 2011;1(2). 
Tableau 1. Caractéristiques des 114 antibiothérapies curatives évaluées à 72 heures

Table 1. Characteristics of the 114 curative antibiotic therapies assessed at 72 hours

\begin{tabular}{|c|c|c|c|}
\hline & $\mathrm{n} / \mathrm{N}$ & $\%$ & $95 \% \mathrm{Cl}$ \\
\hline \multicolumn{4}{|l|}{ Wards } \\
\hline Medicine & $49 / 11$ & 43 & $34-53$ \\
\hline Geriatrics & $26 / 11$ & 23 & $15-32$ \\
\hline Surgery & $24 / 11$ & 21 & $14-30$ \\
\hline Intensive care unit & $15 / 11$ & 13 & $8-21$ \\
\hline \multicolumn{4}{|l|}{ Infection portal of entry } \\
\hline Lungs & $28 / 11$ & 25 & $17-34$ \\
\hline Urinary tract & $27 / 11$ & 24 & $16-33$ \\
\hline Intra-abdominal & $20 / 11$ & 18 & $11-26$ \\
\hline Bone and joint & $10 / 11$ & 9 & $4-16$ \\
\hline Genitals & $7 / 114$ & 6 & $3-12$ \\
\hline Bacteremia/catheter-related & $7 / 114$ & 6 & $3-12$ \\
\hline Other & $6 / 114$ & 5 & $2-11$ \\
\hline Skin and soft tissues & $5 / 114$ & 4 & $1-10$ \\
\hline Febrile neutropenia & $4 / 114$ & 3 & $1-9$ \\
\hline \multicolumn{4}{|l|}{ Origin of the infection } \\
\hline Community-acquired & $49 / 11$ & 43 & $34-53$ \\
\hline Healthcare-associated & $58 / 11$ & 51 & $41-60$ \\
\hline Unknown & $7 / 114$ & 6 & $3-12$ \\
\hline \multicolumn{4}{|l|}{ Microbiological documentation at } \\
\hline Yes & $71 / 11$ & 62 & $53-71$ \\
\hline Negative or flora & $20 / 11$ & 18 & $11-26$ \\
\hline Ongoing & $7 / 114$ & 6 & $3-12$ \\
\hline Not performed & $16 / 11$ & 14 & $8-22$ \\
\hline \multicolumn{4}{|l|}{ Bacteria } \\
\hline Enterobacteriaceae & $57 / 11$ & 52 & $42-61$ \\
\hline Other Gram-negative bacilli & $12 / 11$ & 11 & $6-18$ \\
\hline Gram-positive cocci & $36 / 11$ & 32 & $24-42$ \\
\hline Gram-negative cocci & $2 / 110$ & 2 & $0-6$ \\
\hline Anaerobes & $2 / 110$ & 2 & $0-6$ \\
\hline Gram-positive bacilli & $1 / 110$ & 1 & $0-5$ \\
\hline \multicolumn{4}{|l|}{ Number of antibiotics prescribed } \\
\hline One antibiotic & $66 / 11$ & 58 & $48-67$ \\
\hline Two antibiotics & $40 / 11$ & 35 & $26-45$ \\
\hline Three or four antibiotics & $8 / 114$ & 7 & 3-13 \\
\hline \multicolumn{4}{|l|}{ Antibiotic classes prescribed on } \\
\hline penicillin & $43 / 17$ & 25 & $19-33$ \\
\hline cephalosporins & $43 / 17$ & 25 & $19-33$ \\
\hline carbapenems & $15 / 17$ & 9 & $5-14$ \\
\hline metronidazole & $18 / 17$ & 11 & $6-16$ \\
\hline quinolones & $16 / 17$ & 9 & $5-15$ \\
\hline carbapenems & $15 / 17$ & 9 & $5-14$ \\
\hline glycopeptides & $10 / 17$ & 6 & 3-11 \\
\hline aminoglycosides & $9 / 170$ & 6 & $3-10$ \\
\hline macrolides & $6 / 170$ & 3 & $1-8$ \\
\hline Various classes & $10 / 17$ & 6 & $3-11$ \\
\hline \multicolumn{4}{|l|}{$\begin{array}{l}\text { Route of administration of the } \\
\text { antibiotic therapy on Day } 1\end{array}$} \\
\hline Parenteral & $152 / 1$ & 89 & 84-94 \\
\hline Oral & $18 / 17$ & 11 & $6-16$ \\
\hline
\end{tabular}


\begin{tabular}{lrrrrr}
$\begin{array}{l}\text { Change in antibiotic } \\
\text { between Day } 1 \text { and Day } 3\end{array}$ & therapy & $40 / 11$ & 35 & $26-45$ \\
\hline
\end{tabular} 
Tableau 2. Conformité ${ }^{\mathrm{a}}$ des 114 antibiothérapies évaluées à 72 heures

Table 2. Adequacy ${ }^{a}$ of the 114 curative antibiotic therapies assessed at 72 hours

With microbiological documentation at 72 hours

$\mathrm{n} / \mathrm{N} \quad \% \quad 95 \%$

Antibiotic therapy prescribed at 72 hours active against the documented bacteria

$69 / 71 \quad 97 \quad 90-100$

Active antibiotic therapy prescribed at 72 hours, with an appropriate spectrum

$44 / 71 \quad 62 \quad 50-73$

De-escalation performed at 72 hours if extended spectrum on Day 1

$21 / 48 \quad 44 \quad 29-59$

No microbiological documentation at $\mathbf{7 2}$ hours

$\begin{array}{llll}\text { Compliance of the antibiotic therapy with guidelines } & 32 / 43 & \mathbf{7 4} & 59-86\end{array}$ Adequate antibiotic therapy ${ }^{\mathrm{a}}$

$76 / 114 \quad 67 \quad 57-75$

${ }^{\text {a }}$ Adequate antibiotic therapy $=$ in the presence of a microbiological documentation: active antibiotic therapy with an adequate spectrum or in the absence of microbiological documentation: compliance of the antibiotic therapy with the local or national guidelines. 
Tableau 3. Traçabilité des informations retrouvées dans les dossiers médicaux pour

Table 3. Documentation of the 114 antibiotic therapies assessed at 72 hours in the medical records

\begin{tabular}{|c|c|c|c|}
\hline & $n / N$ & $\%$ & $95 \% \mathrm{Cl}$ \\
\hline \multicolumn{4}{|l|}{ Antibiotic therapy reevaluation } \\
\hline${ }^{a}$ Clearly documented at 72 hours & $45 / 114$ & 39 & $30-49$ \\
\hline Clearly documented after 72 hours & $10 / 114$ & 9 & 4-16 \\
\hline${ }^{\mathrm{a}}$ Tacitly documented at 72 hours & $24 / 114$ & 21 & $14-30$ \\
\hline Tacitly documented after 72 hours & $4 / 114$ & 4 & $1-9$ \\
\hline No documented reassessment & $31 / 114$ & 27 & $19-36$ \\
\hline $\begin{array}{l}\text { Planned duration of the antibiotic therapy } \\
\text { mentioned in the medical record }\end{array}$ & $63 / 114$ & 55 & $46-65$ \\
\hline $\begin{array}{l}\text { Clearly documented reassessment at } 72 \text { hours + } \\
\text { planned duration }\end{array}$ & $29 / 114$ & 25 & $18-34$ \\
\hline $\begin{array}{l}\text { Diagnosis leading to the antibiotic therapy } \\
\text { prescription documented on Day } 1\end{array}$ & $94 / 114$ & 82 & 74-89 \\
\hline $\begin{array}{l}\text { Documented advice from an antibiotic lead } \\
\text { specialist }\end{array}$ & $23 / 114$ & 20 & $13-29$ \\
\hline
\end{tabular}

